\title{
Capital and Firm Specific Characteristics: An Examination of the Survival of Deposit-Taking Financial Institutions (DFI) in Latin America and the Caribbean during the Financial Crisis
}

\author{
Twila Mae Logan ${ }^{1} \&$ Doreen J. Gooden ${ }^{2}$ \\ ${ }^{1}$ Mona School of Business and Management, University of the West Indies, Mona, Jamaica \\ ${ }^{2}$ Florida International University, Miami, Florida, USA \\ Correspondence: Twila Mae Logan, Mona School of Business and Management, University of the West Indies, \\ Mona, Jamaica. E-mail: twilamae.logan@uwimona.edu.jm
}

Received: July 13, 2017

Accepted: August 12, 2017

Online Published: August 25, 2017

doi:10.5539/ijef.v9n10p21

URL: https://doi.org/10.5539/ijef.v9n10p21

\begin{abstract}
This paper aims to assess how capital influences the likelihood of survival of Latin American and Caribbean financial institutions during normal economic times, and the 2008 financial crisis. These financial institutions operate in developing economies that are vulnerable to externals shocks, characterized by large foreign institutions, small indigenous institutions, and high dependence on bank financing due to underdeveloped capital markets. The study uses logistic regressions to estimate the likelihood of survival for three non-overlapping periods - pre, post, and during the 2008 recession. Bankscope provided both financial and firm characteristics (ownership and organizational structures) data. Separate analyses were done based on the size of the institutions. The paper provides empirical indicating that different factors influence the survival of large and small institutions. Higher capital ratios increase the likelihood of survival during the post-recession period especially for smaller institutions. In general, smaller indigenous institutions were less likely to survive. Bank regulators in the regions can use the results of this study to increase their understanding of the factors that influence the failure of financial institutions during different economic periods. This knowledge can be used to implement modifications in how existing regulations are applied to different types of financial institutions. This paper identifies the role of capital, ownership and institutional structures, and size in assessing the likelihood of survival during periods of varying economic activities in developing economies. The paper also highlights similarities and differences with studies conducted in developed economies.
\end{abstract}

Keywords: capital ratios, survival, recession, deposit taking institutions, Caribbean, Latin America

\section{Introduction}

The Great Recession of 2008, like the Great Depression of the 1930s, was as a result of failures in the financial sector. The economic downturn in this sector has severe implications for the economic development of countries, as the financial sector can be viewed as the "engine", which drives economic activities. Thus, survival of firms in the financial sector is of importance, not only to the institution's decision makers, but also to regulators who are concerned about financial sector stability (Berger \& Bouwman, 2013). According to Athanasoglou et al. (2008) when there is a sound and profitable banking sector, it is able to withstand negative shocks, thereby contributing to the stability of the financial system. Many studies have shown that capital can enhance the firm's probability of survival. Cole and White (2012) found that banks with more capital, better asset quality, higher earnings, and more liquidity are less likely to fail.

Extant literature examines the consequences of the Great Recession on the performance of deposit-taking institutions in developed economies. However, there is little evidence of studies examining how deposit-taking institutions in Latin America and the Caribbean weathered the Great Recession. This is particularly important, as the concentration of banking assets in these smaller, less developed markets, is much greater than in more developed markets such as the U.S. Evidence from the World Development Indicators database (World Bank) indicates that in 2013, the average concentration (market share) of the top five banks in the countries studied averaged over $80 \%$, while the corresponding concentration for the U.S. is $35 \%$. Thus, failure of any large deposit taking institution in these countries can have significant impact on vulnerable economies. This paper, therefore, 
aims to add to the existing literature by investigating the factors that influence failure of financial institutions in developing economies, and to determine if these factors are similar to those for developed economies. Studies on financial institutions across different geographical regions are important, because as financial markets become more integrated, regulators are encouraged to adopt global regulations and rules. However, adoption of global regulations and rules by developing countries' regulators is optimal, only if, the issues that impact safety and soundness for these economies are similar to those of developed economies.

We investigated how capital (measured by total equity to total assets) impacts the survival of deposit-taking financial institutions (DFI) in Latin America and the Caribbean, and how this impact varied over 3 periods: pre-recession, during the recession, and post-recession.

We also investigated whether survival is related to the institution's specific characteristics, including, ownership and organizational structures, profitability, and size.

This paper seeks to answer the following research questions:

What role does equity capital plays in DFI's survival?

How does this role differ pre, post and during the 2008 Recession?

How is the role different for small institutions vs large institutions?

\section{Literature Review}

There is limited literature on deposit-taking financial institutions (DFI) in Latin America and the Caribbean during the financial crisis. Thus, our review of the literature is primarily based on a limited number of studies done on financial institutions during financial crises in other countries.

Capital remains an important focus for regulators as it provides a buffer against bankruptcy, deposit insurance funds, and acts a vehicle for governance (Mehran, Morrison, \& Shapiro, 2011). Morrison and White (2005) associate capital with theories of "moral hazard" and "safety net". Relating to the moral hazard theory, they posit that if banks do not have sufficient equity, then decision makers can make decisions that might be advantageous to the shareholders, but suboptimal to the larger society. Thus, they argued that capital could combat "moral hazard" if there is a strong monitoring regulatory system in place. The safety net theory suggests that banks with capital can provide a cushion during periods of adversities. Athanasoglou et al. (2008), also confirmed that bank capital acts as a safety net in the case of adverse developments.

Beltratti and Stulz (2012) found that banks with more capital performed better during the crisis. Berger and Bouwman (2013) posit that higher capital reduces the probability of default and this also supports Estrella et al. (2000) findings that banks with higher capital had lower probability of failure.

The literature shows that other firm-specific characteristics impact on survival of firms.

Banks with more capital, better asset quality, higher earnings, and more liquidity are less likely to fail (Cole \& White, 2012). Zheng et al. (2012) suggest that banks with more liquid assets have a smaller target capital buffer requirement. Poor asset quality and low levels of liquidity are the two major causes of bank failures Athanasoglou et al. (2008).

Berger and Bouwman (2013) suggested that bank size should have a positive impact on survival, since there is a higher probability of the survival of larger banks than smaller banks. Beltratti and Stulz (2012) found that large banks with more Tier 1 Capital and more deposits, performed better during the crisis. According to Zheng et al. (2012) there is the assumption that big companies are safer, which could explain why big companies have lower level of capitalization.

Berger and Bouwman (2013) examined how capital affects banks' performance and how the effect varied across banking crises, market crises, and normal times. They found that capital helps small banks to increase probability of survival and market share at all times (banking crises, market crises and normal times). They also found that capital enhances large banks' survival during banking crises only.

In examining how bank ownership impacted credit supply during the financial crisis in Russia, Fungacova et al. (2013) found that credit reduction was greater for foreign banks than state-controlled banks. This is consistent with Allen et al. (2013) finding that during the global financial crisis, foreign-owned banks in Central and Eastern Europe reduced their credit base while government-owned banks expanded. However, in contrast, they found during domestic crisis the credit base for the foreign-owned banks increased and the government-owned contracted.

Based on prior literature, the following hypotheses were tested using the full sample and two sub-samples based 
on institution size.

$\mathrm{H}_{1}$ : Higher pre-period capital ratio increases the likelihood of survival.

$\mathrm{H}_{2}$ : Majority foreign-owned banks are more likely to survive.

$\mathrm{H}_{3}$ : Parent companies are more likely to survive.

$\mathrm{H}_{4}$ : Higher pre-period credit quality increases the likelihood of survival.

$\mathrm{H}_{5}$ : Larger institutions are more likely to survive.

$\mathrm{H}_{6}$ : Higher pre-period profitability increases the likelihood of survival.

$\mathrm{H}_{7}$ : Higher level of pre-period liquidity increases the likelihood of survival.

\section{Methods}

Using a similar methodology to Berger and Bouwman (2013), we examined how equity capital, as measured by the ratio of equity capital to total assets, impacts the institution's ability to survive. The period under study is 2001-2013. This period was divided into several time bands. We defined three event periods: Pre 2008 Recession (2003-2005), the Recession (2008-2009) and Post-Recession (2012-2013). We used the two-year periods (computation period) prior to the event to compute the equity ratio and firm characteristics. There were no overlaps between the pre-periods and the event periods as indicated in Figure 1.

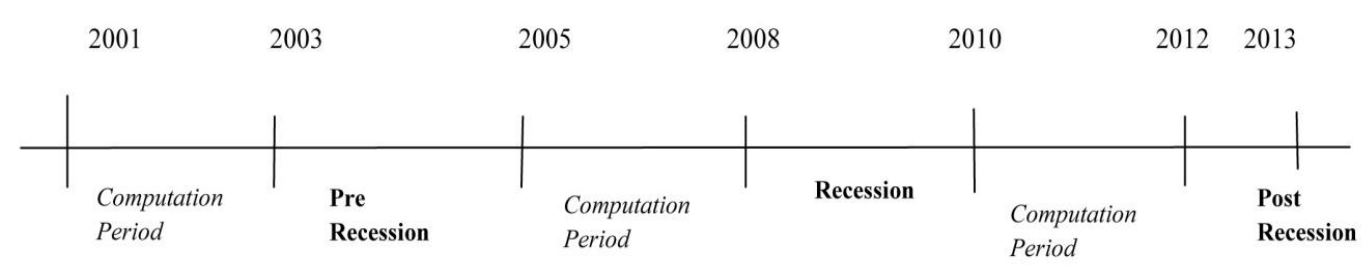

Figure 1. Time line of event and computation periods

The research model used to determine the impact of capital and firm characteristics on survival is as follows:

$$
\text { Survival }=\alpha+\beta_{1} \boldsymbol{\delta}_{1} \text { xEqrat }_{\text {pre }}+\beta_{2} \delta_{2} \text { EEqrat }_{\text {recession }}+\beta_{3} \delta_{3} x \text { Eqrat }_{\text {post }}+\gamma X_{i}+\varepsilon_{i}
$$

Survival is a 0/1 dummy, with 1 representing survival and 0 otherwise. Eqrat pre $_{\text {eqrat }}$ pre and Eqrat post $_{\text {are }}$ the equity ratios (the ratio of equity capital to total assets) in each of the three computation periods. Estrella et al. (2000) found that more complex measures of capital, such as risk weighted capital ratios, are no better at predicting bank failure than simple capital ratios. $\delta_{\mathrm{i}}$ is a $0 / 1$ dummy denoting the three event time periods. For example, if Bank A survived the pre-recession period, but failed during the recession, then Bank A would be listed twice, - in the first instance Survival and $\delta_{1}$ are coded 1 , and $\delta_{2}$ coded 0 . In the second instance, Survival and $\delta_{1}$ are coded 0 while $\delta_{2}$ is coded $1 . \mathrm{X}_{\mathrm{j}}$ represents a vector of institution specific variables.

The institution specific variables are:

Size - measured by the log of total assets at the beginning of each the 3 periods.

Credit - the ratio of the reserve for non-performing loans to total loans

Liquidity - the ratio of cash and due from other banks to total assets

Ownership - 0/1 dummy variable where, 1 represents indigenous banks, and 0 represents foreign owned banks.

Structure - an indicator variable that denoted the organizational structure of the institution. The structures are: branch, controlled subsidiary, global ultimate owner (parent firm), and independent firm.

Return on Equity - a measure of the profitability of the institution.

All the independent variables (except for size) were averaged over the two-year period prior to the event. For example, for the pre-recession period of 2003-2005, data was averaged over the 2001-2002 period.

We estimated the research model using logistics regression. Data for the three periods was combined in a single regression model. Recognizing that some institutions had data for each of the three periods, we ran clustered regressions (by institution) and computed robust standard errors to reduce problems of heteroscedasticity.

\subsection{Data Description}

We obtained data from the Bankscope database on 338 different institutions from twenty Latin American and 
Caribbean countries, (see Appendix 1 for the list of countries). These countries were chosen based on geography and the perceived level of financial market development. The countries were either islands in the Caribbean Sea or had coastlines around the Caribbean Sea. Mexico and United States were eliminated because of their size and stage of development. Islands including the Bahamas and the Cayman Islands were also eliminated due to the large number of offshore financial institutions in those countries.

Table 1 presents a summary of the number of institutions that survived in each of the three periods. Surprisingly, the number of institutions that survived the recession was very similar to the number that survived during the pre-recession period. Interestingly though, only a few institutions did not survive the post-recession period. As indicated earlier, there were some institutions that were represented in more than one of the three sample periods resulting in a total of 590 data points from 338 institutions.

Table 1. Descriptive statistics on survivorship

\begin{tabular}{lccc}
\hline Period & Survived & Did not Survived & Total \\
\hline Pre (2003-2005) & 167 & 38 & 205 \\
Recession (2008-2009) & 163 & 28 & 191 \\
Post (2012-2013) & 190 & 4 & 194 \\
\hline
\end{tabular}

Source: Bankscope Database and authors' computations.

For two- year period prior to each of the periods, the average return on equity was about $15 \%$, while the average equity to total assets was $12 \%$, and the average liquidity (measured by cash and amount due from other banks) was about $12 \%$ of assets. The distribution of credit (measured by provision for loan loss as a percentage of total loans) and the size of the institutions were highly skewed, as the mean values were much larger than the median values. The mean credit quality (measured by the reserves for non-performing loans to total loans) was $336 \%$ times while the median was only $3 \%$. The mean asset size was US\$5,296 million vs the median of US\$188 million. (See Table 2).

Table 2 Descriptive data - Pooled over the three periods

\begin{tabular}{lccccc}
\hline & ROE & Credit & Capital & Liquidity & Assets (\$ mil) \\
\hline Mean & 0.15 & 3.36 & 0.12 & 0.12 & 5,296 \\
Median & 0.14 & 0.03 & 0.12 & 0.10 & 188 \\
\hline
\end{tabular}

Note. ROE is Return on Equity, Credit is the ratio of reserves for non-performing loans to total loans, and Capital is the capital ratio measured as equity capital to total assets, Liquidity is the ratio of cash and due from other banks to total assets.

Source: Bankscope Database and authors' computations.

\section{Results of Logistic Regressions}

Using the research model in equation 1, we ran three sets of logistic regression - (i) all institutions, (ii) institutions with assets $<\$ 100$ million in assets and (iii) with institutions with assets $>$ US $\$ 1$ billion in assets. The results are presented in Tables 3-5. Examining the entire sample, (see Table 3) a higher capital ratio increased the odds of survival in the pre-recession period (2003-2005) by about $4 \frac{1}{2}$ times, and is significant at the $1 \%$ level of significance. Higher capital ratios also significantly increased the odds of survival in the post-recession period by over $700,000 \%$, suggesting with certainty, that institutions with larger capital ratios will survive in the post-recession period. Although this is highly significant ( $\mathrm{p}$ value $=1.5 \%$ ) it may be not be meaningful, as there were only a few institutions (four) that did not survive the post-recession period. Thus, the large odds ratios may be driven by small numbers, than by economic significance. Surprisingly, higher capital ratios did not increase the likelihood of surviving the recession. In fact, institutions with higher capital ratios resulted in these institutions being less likely to survive the recession. However, this was not statistically significant. Thus, we have partial support for $\mathrm{H}_{1}$ (higher pre-period capital ratio increases the likelihood of survival) for non-recession periods, but not for during the recession.

The institutional specific variables, which include ownership, organization structure, and credit quality, were significant in explaining the probability of survival. $\mathrm{H}_{2}$ : Majority foreign-owned banks are more likely to survive was supported, as indigenous institutions were 66\% less likely to survive when compared to institutions that were majority foreign owned ( $\mathrm{p}$ value of $1.3 \%$ ). We also found support for $\mathrm{H}_{3}$ (Parent companies are more likely to survive) as parent company institutions (global ultimate owners -GUO) increased their odds of surviving by 
over 8 times. Although institutions with lower credit quality (provision for non-performing loans to total loans) had statistically higher odds ratio of 1.01, this was not economically significant, and, therefore, $\mathrm{H}_{4}$ - higher pre-period credit quality increases the likelihood of survival - is not supported. Size (log of total assets), profitability (return on equity) and liquidity (ratio of cash and due from other banks to total assets) all increased the odds of survival; however, this increase was not statistically significant.

Table 3. Logistic regression with survival as the dependent variable ( 1 if the institution survived and 0 otherwise) for all institutions

\begin{tabular}{lllll}
\hline & Odds Ratio & p-value & Marginal Effects & p-value \\
\hline Constant & 4.55 & 0.173 & & 0.001 \\
Eqrat*Pre & 4.53 & 0.001 & 0.14 & 0.015 \\
Eqrat*Post & 788499 & 0.015 & 1.24 & 0.482 \\
Eqrat*Recession & 0.35 & 0.483 & -0.01 & 0.394 \\
Liquidity & 3.01 & 0.392 & 0.10 & 0.380 \\
Size & 1.18 & 0.378 & 0.01 & 0.016 \\
Credit & 1.01 & 0.019 & 0.001 & 0.013 \\
Ownership & 0.34 & 0.013 & -0.10 & 0.765 \\
ROE & 1.05 & 0.766 & 0.004 & 0.044 \\
Structure (GUO) & 8.14 & 0.043 & 0.19 & \\
R : $15.26 \%, \mathrm{n}=588(388) ;$ Wald $\chi$ & $=42.18$ (p-value: 0.0000$)$ & & \\
\hline
\end{tabular}

Note. Pre, Post and Recession are 0/1 dummy variables representing the periods before, after and during the 2008 Recession. Eqrat is the capital ratio measured as equity capital to total assets, ROE is return on Equity, Liquidity is the ratio of cash and due from other banks to total assets, Credit is the ratio of reserves for non-performing loans to total loans, Ownership is a 0/1 dummy ( 1 for indigenous banks and 0 for foreign owned banks) and Structure - an indicator variable that denoted the organizational structure of the institution (branch, controlled subsidiary, global ultimate owner (parent firm), and independent firm).

Thus, there is no strong evidence to support $\mathrm{H}_{5}, \mathrm{H}_{6}$ and $\mathrm{H}_{7}$. The last two columns of Table 3 provide information of the marginal effects and p-values of the independent variables. Analysis of the p-values for marginal effects (last 2 columns in Table 3 ) is essentially the same as the p-values for the odds ratios, indicating that the statistical significance of the odd ratios is robust.

The logistic regression was done using small institutions (assets $<$ US\$100 million) and the results are shown in Table 4. Higher equity ratios increased the odds of survival at all times, but this increase was only statistically significant during the pre-recession period. Similar to the full sample, indigenous institutions were less likely to survive, but this was not statistically significant ( $\mathrm{p}$ value $=0.167$ ).

Table 4. Logistic regression with survival as the dependent variable ( 1 if the institution survived and 0 otherwise) for institutions with assets < US $\$ 100$ million

\begin{tabular}{lllll}
\hline & Odds Ratio & p-value & Marginal Effects & p-value \\
\hline Constant & 1.80 & 0.787 & & \\
Eqrat*Pre & 5.53 & 0.003 & 0.20 & 0.001 \\
Eqrat*Post & 47013 & 0.071 & 1.26 & 0.071 \\
Eqrat*Recession & 3.30 & 0.613 & 0.14 & 0.611 \\
ROE & 1.05 & 0.749 & 0.005 & 0.748 \\
Liquidity & 3.50 & 0.517 & 0.15 & 0.519 \\
Size & 1.32 & 0.513 & 0.03 & 0.513 \\
Credit & 1.01 & 0.017 & 0.001 & 0.013 \\
Ownership & 0.273 & 0.167 & -0.15 & 0.166 \\
Structure & 0.10 & 0.543 & 0.11 & 0.543 \\
R : $15.49 \%, \mathrm{n}=216(182) ;$ Wald $\chi=20.52(\mathrm{p}$-value: 0.0150$)$ & & &
\end{tabular}

Note. Pre, Post and Recession are 0/1 dummy variables representing the periods before, after and during the 2008 Recession. Eqrat is the capital ratio measured as equity capital to total assets, ROE is return on Equity, Liquidity is the ratio of cash and due from other banks to total assets, Credit is the ratio of reserves for non-performing loans to total loans, Ownership is a 0/1 dummy ( 1 for indigenous banks and 0 for foreign owned banks) and Structure - an indicator variable that denoted the organizational structure of the institution (branch, controlled subsidiary, global ultimate owner (parent firm), and independent firm). 
Again, institutions with lower credit quality had statistically significant increased odds of survival, but with limited economic significance (marginal effect is 0.001). Size (log of total assets) and profitability (return on equity) and liquidity (ratio of cash and due from other banks to total assets) all resulted in increased odds of survival, however, the increase was not significant. Analysis of the p-values for marginal effects (last 2 columns in Table 4) is essentially the same as the p-values for the odds ratios, indicating that the statistical significance of the odd ratios is robust.

Table 5. Logistic Regression with survival as the dependent variable ( 1 if the institution survived and 0 otherwise) for institutions with assets > US\$1 billion

\begin{tabular}{|c|c|c|c|c|}
\hline & Odds Ratio & p-value & Marginal Effects & p-value \\
\hline Constant & 0.00002 & 0.174 & & \\
\hline Eqrat*Pre & 21.28 & 0.789 & 0.17 & 0.788 \\
\hline Eqrat*Post & 66817 & 0.119 & 0.64 & 0.151 \\
\hline Eqrat*Recession & 0.001 & 0.086 & -0.42 & 0.107 \\
\hline ROE & 0.004 & 0.187 & -0.31 & 0.216 \\
\hline Liquidity & 1.79 & 0.867 & 0.03 & 0.867 \\
\hline Size & 8.90 & 0.075 & 0.12 & 0.091 \\
\hline Credit & 0.001 & 0.233 & -0.40 & 0.222 \\
\hline Ownership & 0.06 & 0.018 & -0.16 & 0.024 \\
\hline Structure & 2.66 & 0.069 & 0.06 & 0.014 \\
\hline \multicolumn{5}{|c|}{$\mathrm{R}: 39.15 \%, \mathrm{n}=120(94) ;$ Wald $\chi=34.10$ (p-value: 0.0001$)$} \\
\hline
\end{tabular}

Note. Pre, Post and Recession are 0/1 dummy variables representing the periods before, after and during the 2008 Recession. Eqrat is the capital ratio measured as equity capital to total assets, ROE is return on Equity, Liquidity is the ratio of cash and due from other banks to total assets, Credit is the ratio of reserves for non-performing loans to total loans, Ownership is a 0/1 dummy (1 for indigenous banks and 0 for foreign owned banks) and Structure - an indicator variable that denoted the organizational structure of the institution (branch, controlled subsidiary, global ultimate owner (parent firm), and independent firm).

Table 5 presents the result of the logistic regression using the large institutions (assets > US $\$ 1$ billion). These results suggest that for larger institutions, the odds of survival marginally increased with size, as well as for institutions with a greater independent organizational structure. Indigenous institutions are significantly less likely to survive. Increased capital ratios increased the odds of survival in post and pre-recession periods, but not significantly. However, increased capital ratios marginally decreased the odds of survival during the recession. Though increased liquidity increased the odds of survival, this was not statistically significant. Greater profitability (ROE) and lower credit quality reduced the odds of survival, but this was not statistically significant. The marginal effects, however, were relatively high ( -0.31 and -.40 respectively). Institutions with lower credit quality (relatively higher loan loss provisions) could have a higher profitability of failure, as lower quality loans would attract higher yields). Analysis of the p-values for the marginal effects (last 2 columns in Table 5) is essentially the same as the p-values for the odds ratios, indicating that the statistical significance of the odd ratios is robust.

\section{Discussion}

The results presented in Tables 3-5 suggest that having higher levels of capital enhances the institution's ability to survive during non-crisis period, but not during the period of recession 2008-2009. This effect was more important for smaller institutions. Surprisingly, higher levels of capital did not increase the odds of surviving the recession. In fact, higher capital marginally reduced the odds of survival, especially for the larger institutions. These findings are consistent with Cole and White (2012) who found that in 2004, banks with higher capital were more likely to fail, and for other years, higher capital was associated with increased survival. However, other researchers, and (Beltratti \& Stulz, 2012), found that higher levels of capital increase the odds of institutions surviving during normal times and times of crises especially for smaller institutions (Berger \& Bouwman, 2013). Thus, the literature is split on the role of capital in survival of financial institutions. During normal times, the risk models allow managers to predict credit and other operational risks, thus they are able to identify the appropriate amount of capital needed to buffer against decline in asset values. However, models that work during normal periods may prove inadequate during times of crises especially one that is as impactful as the Great Recession of 2008. Smaller institutions are expected to be more adversely affected as they may have lower levels of managerial expertise, inability to raise funds on the capital markets, and not large enough to 
benefit from being "too big to fail". In addition, in a flight to quality, clients may abandon smaller institutions in favor of larger ones or move funds to safer instruments denominated in hard currency. The latter is true for emerging market economies where the domestic currency is susceptible to large devaluation or depreciation in response to international shocks that significantly impact the domestic economy.

Should regulators in the Latin American and Caribbean regions then require higher capital ratios for smaller institutions? This can be justified by arguing that smaller institutions are less likely to be able to access the capital markets in the event of a crisis, thus a greater capital buffer will be critical during periods of crises. However, higher capital requirements can impede the institutions ability to grow and, more importantly, provide the necessary credit. This is especially problematic in these economies where the capital markets are poorly developed and firms are overly reliant on banks for credit than those in developed economies.

The results of this study indicate that ownership matters; that is, institutions with majority foreign owners, are more likely to survive. The existing literature is split on this subject. Berger and Bouwman (2013) was unable to find evidence that foreign ownership increased the odds of survival. In fact, they found that foreign ownership, marginally decreased the likelihood of survival for small banks only. On the other hand, Logan (2006) found that none of the majority foreign owned banks failed during the banking crisis in Jamaica in the 1990's. For developing countries (in Latin America and the Caribbean) foreign owners are usually other financial institutions from developed countries - Canada (in the Caribbean region), USA, and western European countries. Financial institutions from these countries may have more robust managerial systems, as having the ability to address any capital deficiency in their subsidiaries or branches (Ongore \& Kusa, 2013). Beltratti and Stultz (2012) also found that banks from countries with more banking restrictions performed better during the crisis.

Overall, financial institutions that are "global ultimate owners" (parent companies) appear to have higher odds of survival. This is a similar to Berger and Bouwman's (2013) finding that bank holding companies are less likely to fail. There are several possible reasons - (i) these are conglomerates, and therefore, are more diversified than banks with single location or as a branch, hence reducing the likelihood of failure, (see (Torna, 2010) for a more detailed discussion on whether diversification helps or hinders the bank's holding company's ability to survive).

(ii) These institutions may also be able to reallocate resources among the subsidiaries more effectively than an institution with a single location, or an independent institution. This flexibility allows the conglomerates to respond to the changing market conditions in a timely fashion, thereby ensuring greater survival rates.

For larger institutions, size is a major factor, as increased firm size increases the likelihood of survival, and this is consistent with Berger and Bouwman (2013) and Wheelock and Wilson (2004). Larger banks are more likely to benefit from the too big to fail (TBTF) doctrine as regulators are reluctant to close large institutions for fear of contagion (Mehran, Morrison, \& Shapiro, 2011).

\section{Conclusion}

The empirical evidence from earlier studies of bank failures in developed economies indicates that higher levels of capital, liquidity, and credit quality increased the likelihood of survival. This study found that only higher levels of capital had a significant and economic impact on the probability of institutions surviving during normal economic periods. Similar to other studies, we found that size and organizational structure had significant impact, with larger institutions and parent firms being more likely to survive. However, this study indicates that foreign ownership, especially for larger institutions, significantly improved the likelihood of survival.

One important revelation from this study is for regulators to recognize the importance of requiring extra capital to ensure the safety and soundness of the financial sector. While higher pre-period capital increases the odds of survival in "normal" periods, higher pre-period capital did not increase the likelihood of survival during the recession. Regulators may need to consider other factors to ensure safety and soundness during periods of crises as it apparent that higher capital may not be sufficient. This is not inconsistent with Koehn and Santomero (1980) who posit in their theoretical paper that increasing capital requirement may not always lead to reduced probability of failure. The results also suggest that regulators in the Latin American and Caribbean regions need to cognizant that the factors that impact the survival rates for large institutions are different from those for the smaller institutions. Thus, regulators in these regions should focus on smaller indigenous institutions, as these are the firms that have increased likelihood of failure.

\section{References}

Allen, F., Jackowicz, K., \& Kowalewski, O. (2013). The effects of foreign and government ownership on bank lending behavoir during a crisis in Central and Eastern Europe. MPRA. Retrieved from https://mpra.ub.unimuenchen.de/48059/1/MPRA_paper_48059.pdf 
Athanasoglou, P. P., Brissimis, S. N., \& Delis, M. D. (2008). Bank-specific, industry-specific and macroeconomic determinats of bank profitability. Jounral of International Financial Markets, Institutions and Money, 18(2), 121-136. https://doi.org/10.1016/j.intfin.2006.07.001

Beltratti, A., \& Stulz, R. M. (2012). The credit crisis around the globe: Why did some bank perform better? Journal of Financial Economics, 105(1), 1-17. doi:10.1016/j.fineco.2011.12.005

Berger, A. N., \& Bouwman, C. N. (2013). How does capitalo affect bank peformance during the financial crisis? Journal of Financial Economics, 109(1), 146-176. doi:10.1016/jfineco.2013.02.008

Cole, R. A., \& White, L. J. (2012). Deja Vu all over again: The causes of US commerical bank failures this time around. Journal of Financial Services Research, 42(1-2), 2-29. https://doi.org/10.1007/s10693-011-0116-9

Estrella, A., Park, S., \& Peristiani, S. (2000). Capital Ratios as predictors of bank failure. Federal Reserve Bank of New York Economic Policy Review, 6(2), 33. Retrieved from http://www.ny.frb.org.ezproxy.fiu.edu/research/epr/

Fungacova, Z., Herrala, R., \& Weill, L. (2013). The influence of bank ownership on credit supply: Evidence from the recent financial crisis. Emerging Markets Review, 15, 136-147. doi:10.1016/j.ememar.2013.02.002

Koehn, M., \& Santomero, A. M. (1980). Regulation of bank capital and portfolio risk. Journal of Finance, 35(5), 1235-1244. https://doi.org/10.1111/j.1540-6261.1980.tb02206.x

Logan, T. M. (2006). Investment incentives, risk and ownership forms of commerical banks in emerging markets. Retrieved

from https://www.researchgate.net/publication/241746232_Investment_incentives_risk_and_ownership_forms_o f_commercial_banks_in_emerging_markets

Mehran, H., Morrison, A. D., \& Shapiro, J. D. (2011). Corporate governance and banks: What have we learnt from the finanical crisis. New York: Stall Report No. 502 Federal Reserve Bank.

Morrison, A. D., \& White, L. (2005). Crises and capital requirements in banking. The American Economic Reiew, 95(5), 1548-1572.

Ongore, V. O., \& Kusa, G. B. (2013). Determinants of finanical performance of commerical banks in Kenya. International Journal of Economics and Financial Issues, 3(1), 237. Retrieved from http://www.econjournals.com/index.php/ijefi/issue/archive

Torna, G. (2010). Understanding commerical bank failures in the modern banjing era. Financial Management Association Annual Meeting. New York. Retrieved from http://www.fma.org/NY/Papers/ModernBanking-GTORNA.pdf.2010

Wheelock, D. C., \& Wilson, P. W. (2004). Consolidation in US Banking: Which banks engage in mergers? Review of Financial Economics, 13(1), 7-39. doi:10.1016/j.rfe.2003.09.001

World Bank. (2016). World Development Database. World Bank. World Bank. Retrieved from data.worldbank.org/data-catalog/world-development-indicators

Zheng, C., Xu, T., \& Liang, W. (2012). The empirical research of banks' capital buffer and risk adjustment decision making: Evidence from China's banks. China Finance Review International, 2(2), 163-179. Retrieved from http://www.emeraldinsight.com.ezproxy.fiu.edu/journals.htm?issn=2044-1398

\section{Appendix 1}

List of countries used in study

\begin{tabular}{c}
\hline Anguilla \\
Antigua \& Barbuda \\
Aruba \\
Barbados \\
Belize \\
British Virgin Islands \\
Cuba \\
Dominica \\
Dominican Republic \\
Grenada \\
\hline
\end{tabular}


Guatemala

Guyana

Haiti

Honduras

Jamaica

Nicaragua

St. Kitts \& Nevis

St. Lucia

St. Vincent \& The Grenadines

Trinidad \& Tobago

Venezuela

\section{Copyrights}

Copyright for this article is retained by the author(s), with first publication rights granted to the journal.

This is an open-access article distributed under the terms and conditions of the Creative Commons Attribution license (http://creativecommons.org/licenses/by/4.0/). 